\title{
THE TEACHING AND LEARNING PRACTICE PERFORMED BY PRE- SCHOOL TEACHERS DURING COVID 19 OUTBREAK
}

\author{
Sri Fatmaning Hartatik ${ }^{1)}$, Anis Na'il Fulka Bia’yuni' ${ }^{2)}$ \\ IKIP Budi Utomo \\ fatmaninghartatik@gmail.com
}

\begin{abstract}
Covid 19 outbreak have made all sectors to switch their performance from face to face interaction to virtual ones; from massive gathering and meetings to social distancing. This is also applied in education sector. This study was intended to describe how teaching and learning process took place during the Covid 19 outbreak. This study focused on the teaching and learning process in pre-school level as the researchers wondered how teachers facilitated learning for young learners. From the interview, the researchers noticed that all teachers used WhatsApp to get themselves connected to their students. In addition, they also send the student work book to their students' houses. Next, two teachers needed to teach some students in the classroom as learning from home did not work for few students, the numbers of the students and the meetings of course were limited. The findings of this studies were expected to give insights to stake holders, policy makers, education experts, and scientist to help teachers and learners at pre-school level so that they still can achieve the teaching and learning objectives during the Covid 19 outbreak
\end{abstract}

Key words: Covid 19 outbreak, teaching learning from home, online learning, pre-school

CPendidikan Bahasa Inggris FPISH IKIP BU Malang

\section{Introduction}

The world has been suffering from Corona virus diseases since 2019. The rapid spread of this virus does not only contribute negative impact on health care field but also many sectors as social, economic, transportation, science, and even education. As this virus is transmitted through direct interaction amongst people, face to face interconnection should be minimized. To this, many countries agree that stay-athome movement should be implemented. It was not easy to adapt to this particular situation. All sectors, however, including education need to survive by switching from the traditional activities to the virtual ones. To this, The Indonesian ministry of education uttered a learning from home policy.
Referring to the Ministry of Education and Culture policy through circular letter number 36962 / MPK.A / HK / 2020 all parties involved in the education field should be carried out in an online mode. This policy is applied to all education level starting from Pre-school, Elementary School, Junior High School, Senior High School, and Higher Education levels. Online teaching and learning process might not have too much impact on higher education levels as they, generally, have equipped their institution with adequate facilities such as multimedia laboratory and internet connection to support the online teaching and learning process. Besides, their target learners have also been familiar with the internet and some online media as means of learning and communication. Therefore, learning from home is not a 
significant problem in this education unit. This policy become another thing to deal with when it touches the process of teaching and learning from home at lower education level as it was reported by Atmojo and Nugroho (2020). They found out that though teachers had used many digital platforms to facilitate learning, the teaching and learning process had not run very well since less preparation had been made by all parties as teachers, students, and even parents.

In addition to that many schools do not have proper facilities that can support this online learning mode. Moreover, their targeted learners are still too young to have their own gadgets. If they happen to have the gadgets, sometimes they have a problem with the internet connection. Several media such as Narasi TV and Liputan6 (April 2020) reported that many teachers had to teach door to door in order to help their learners complete the objectives of learning. They need to do it because they do not have sufficient facilities that can get the teachers and learners connected.

In a normal situation, there are always challenge in delivering teaching and learning process. This is due to the fact that teaching and learning should accommodate teaching and learning principles which cover many aspects as the selection of teaching techniques, teaching media, teaching materials, and assessment. The teaching and learning practice become more challenging when these activities are presented in an-online manner. Some studies have investigated the implementation of online learning, especially during the covid 19 pandemic. One of which was done by Allo (2020), Having investigated the teaching and learning process at one of universities in Toraja Indonesia, he found out that online learning for adult learners is good to some extents as this help teachers and learners to stay safe during the pandemic. This learning mode, however, also contributed learning inconvenience in term of financial issue. According to his subjects, as online learning needs much internet data, they need to spend more money for this.

Another study discussing about the teaching and learning process during covid 19 was presented by Nugroho and Atmojo (2020). Different from Allo, Atmojo and Nugroho (2020) observed the teaching and learning practice at secondary levels. One of their findings showed that problem emerged as not all students have their own smart phones so that they were absent when the online class was going on. For those who owned their personal mobile phone, the limited internet connection, sometimes, also hindered them from attending the online classes.

Similar to the aforementioned studies, this study was intended to elaborate the teaching and learning process during Covid 19 outbreak. This study, however, is still significantly different from the previous ones as this study was carried out in different setting and different level of education. Different from Allo's study, this particular study elaborated the teaching and learning practice demonstrated by teachers in Malang, East Java. Compared to Atmojo and Nugroho (2020) this study is also different. The difference laid on the level of education. Nugroho and Atmojo focused on the teaching of English at secondary level; meanwhile, this 
particular study focused on elaborating the teaching and learning practice at preschool level.

\section{Research Method}

The objective of this study was to describe the teaching and learning from home practice carried out by pre-school teachers in Malang. Therefore, the design of this study was descriptive qualitative. To gain the data, the researchers involved pre-school teachers in one of Play Group and Kindergarten schools in Malang. The subjects of the study were interviewed by using interview guide containing open ended questions. The interview was carried out in two ways; by video call and face two face interview. The interview via video call was made in regard to social distancing so that physical interaction among the researchers and the subjects of this study can be minimized. The face to face interview was done as the subjects of the study could not be reached out by video call. In doing face to face interview, the researchers, of course, had considered the Covid 19 health protocols. Both parties, the researchers and the subjects of this study, had normal body temperature, wore masks and face shield, and sit in a two-meter distance during the interview. The results of the interview were transcribed. Then, Similar answers and reasons were classified together. Next, the classified data were described before they were interpreted.

\section{Finding and Discussion}

Based on the results of the interview, teachers in pre-school level in Malang carried out their teaching practice in two ways. First, the teaching and learning process were done in online mode by using WhatsApp as a medium of interaction. And secondly, the teachers still delivered the teaching and learning process conventionally, face to face meeting.

In respect to the government policy dealing with learning from home movement, all teachers in pre-school level in Malang used WhatsApp as a medium of teaching and learning. The very basic reasons they used this mobile phone application was this application is the most applicable in teaching and learning process. This was so as all most of the teachers and parents had this application. In addition to low budget and maintenance, this application provided useful features like short text message, voice notes, video call conference, and picture as well as document sharing. Even though, this medium had quite complete features, the teachers admitted that the struggle in delivering teaching materials was real. In using the video call conference, for example, the teachers could invite three students only; therefore, during online teaching and learning process, they needed to spend more hours to reach their students than they used to do in her conventional class. Another challenge that the teachers faced during online teaching and learning was not all students had a printer to print out the worksheet which had been shared in WA group. Consequently, teachers had to send the hard copy worksheets to their students so that the students still could complete the worksheet at home. Another challenge appeared when both of learners' parents are working parents. This was so because their learners did not have their own mobile phone; so, they used their parents' mobile phones. This 
became a hindrance as the teaching and learning process took place during parents' working hours. As a result, some students missed the online class. To solve with this, teachers usually made a video call with these students in the evening when their parents were already home. Again, teachers had to allocate longer teaching hours than their normal teaching hours. During online teaching and learning, teachers used some online resources as pictures from Google or videos from YouTube. Besides, they also used teacher-self-made worksheet to facilitate the teaching and learning process.

The next teaching practice that pre-school teachers implemented during Covid 19 outbreak was that face to face meeting in the classroom. The teachers admitted that they had had to do it because there had been no other way out to reach out the students. Some students had a problem with the internet connection and data. Some others need to come to the class simply because their parents could not support them to learn from home due to their limitation. Therefore, face to face teaching and learning process in the classroom needed to done when the entered the new normal era. The teachers explained that to minimize the risk of Covid 19 spread, they had lived up the face to face classroom meeting to the Covid 19 health care procedure. The very basic procedure that they applied was only teachers and students with normal body temperature were allowed to participate in the teaching and learning process. Next, wearing a mask, face shield, and washing hands were a must before they entered the classroom. Besides, there were only four students and a teacher in a class per hour in a day. In addition, during the teaching and learning process, physical distancing was also applied so that physical interaction could be minimized. As physical interaction was not allowed, similar to online teaching and learning, they used pictures and videos that they downloaded from the internet as their learning resources. Worksheets were also given but the students were to accomplished their worksheet at home. They could not finish their worksheet at schools as they had very limited time to study at school.

From the presented findings we can see that teachers at pre-school level did make positive efforts in teaching during Covid 19 outbreak. The teaching materials that were selected by the teachers showed that teachers followed teaching principles proposed by experts as Harmer (2007 in Aini 2013: 197-198) who stated that pictures, realia, course book, are appropriate for young learners as these teaching media and materials meet the young learners' characteristics. In addition, the pre-school teachers in one of Play Group and Kindergartens in Malang also seemed to be aware how to stand; they know how to facilitate learning based on the existing context and current needs of both teachers and students. This is in line with Liu (2004: 178) who put that teachers should be able to adapt and adopt teaching method and approaches that suit their teaching context and needs.

The Findings of this study also showed supports the existing study dealing with teaching practice during Covid 19 pandemic. Some students missed the online class as they did not 


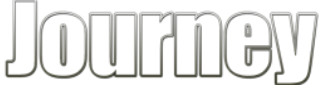

have their own mobile phone. This was exactly the same as what Atmojo and Nugroho (2020) figured out “...students who did not have mobile phone were commonly absent from the online class..." The teachers, however, responded differently; the teachers in this study reorganized the online learning in the evening when the students' working parents were already home. The teacher might be able to do it because the numbers of the students in pre-school level were not as many as the students in secondary levels. In addition to Atmojo and Nugroho (2020), there seemed to be a similar issue existed in this particular study and Allo's (2020) study. The similar issue was about limited connection of the internet. In response to this, the subjects of this study chose to conduct traditional teaching and learning which take place in the school. To minimize the risk of Covid 19 spread, Covid 19 health care procedures were carefully implemented.

\section{Conclusion}

From the findings and discussion above, we can conclude that the Covid 19 outbreak has made pre-school teachers to switch their teaching and learning style from conventional way to blended learning, teaching and learning process that accommodate online and face to face interaction in the classroom. The teachers could not switch totally onto online mode as in their practice they found out some obstacles as not all students possessed personal mobile phone and good internet connection. Besides, the unavailability of printers at students' house got the students unable to finish their worksheet, like drawing and coloring, which had been shared by the teachers WhatsApp group.

\section{Suggestions}

Based on the findings, discussion, and conclusion of this study, the researchers would like to make some suggestion to some parties. First suggestion is addressed to policy makers. They are suggested to readjust their policy on the teaching and learning process during the pandemic, especially the teaching and learning process in preschool education level. Besides, the teaching and learning process during pandemic need to be supported by sufficient technology as internet connection and smart digital devices. Therefore, stakeholders are encouraged to provide teachers and students in need with such kind of facilities. Another suggestion is made for education experts to help teachers at pre-school level to upgrade their teaching skill so that they do not only use WhatsApp as a means of delivering online teaching and learning process but also use any other digital platforms. Finally, further researchers are supported to conduct similar research in different settings and level to contribute deeper insights on teaching and learning process during pandemic. By doing so, it is expected that implementation of teaching and learning process during and after pandemic will be safer and better.

\section{References}

Aini, W. N. (2013). Instructional Media in Teaching English to Young Learners: A Case Study in Elementary Schools in Kuningan. Journal of English Education (196205). 1 (1). Online Journal. 
Retrieved from https://ejournal.upi.edu/index.php/ L-E/article/view/350/239 on 23rd August 2020

Allo, M.D.G. (2020). Is the online learning good in the midst of Covid-19 Pandemic? The case of EFL learners. Jurnal Sinestia, 10 (1), 1-10. Online Journal .Retrieved from https://www.researchgate.net/pub lication/340815846_Is the_onlin e learning_good_in the midst_o f_Covid-

19_Pandemic_The case_of_EFL learners/link/5eb81670299bf128 7f782f3b/download On 23 July 2020

Aldo, M. (2020). Guru SD di Sumenep Mengajar dari Rumah ke Rumah karena Murid Tak Punya HP . Online News. Retrieved from https://www.liputan6.com/region al/read/4232473/guru-sd-disumenep-mengajar-dari-rumahke-rumah-karena-murid-takpunya-hp On May 31st 2020

Atmojo, Arief E.P \& Nugroho, A. (2020). EFL Classes Must Go Online! Teaching Activities and Challenges during COVID-19 Pandemic in Indonesi. Register Journal, 13 (1), 49-76. Online Journal Retrieved from https://www.researchgate.net/pub $\underline{\text { lication/341750033_EFL_Classes }}$ _Must_Go_Online_Teaching_Ac tivities_and_Challenges_during COVID-

19_Pandemic_in_Indonesia On August 12th

Kemendikbud. (2020). Edaran Bekerja dan Belajar dari rumah. (Online)
Retrieved from

https://www.kemdikbud.go.id/ma in/blog/2020/03/se-mendikbudpembelajaran-secara-daring-danbekerja-dari-rumah-untukmencegah-penyebaran-covid19

Liu, J. (2004). Methods in the postmethods era Report on an international survey on language teaching methods. International Journal of English Study. 4 (1). Online Journal. Retrieved from https://files.eric.ed.gov/fulltext/E J1072190.pdf on 25th April 2020

Narasi Newsroom. (2020). Demi Siswa, Guru Mengajar dari Rumah ke Rumah. Online News. Retrieved https://www.narasi.tv/narasinewsroom/demi-siswa-gurumengajar-dari-rumah-ke-rumah on $\underline{31 \text { May } 2020}$ 